\title{
Prior OCCUPATION and SChismatic Principles: TOWARD a NORMATIVE ThEORIZATION OF ABORIGINAL TITLE
}

\author{
DWIGHT G. NEWMAN
}

There are wo divergen principles tuderlying the constitutional recognition of Aboriginat title ins. 35(I) of the Constitution Act, 1982: /he hisforically-oriented principle of "prior occupation." and the fonvardlooking principle of "reconcilianion. "A closer look at the principle of "prior occupation" reveals several possible rationales behind its requirement in the test for Aboriginal sille: to promole economic efficienci; to ground a natural right of ownership: and to function as a proxy for the protection of individual or group identity. However, each of these rationales fails in adequately respond to both previous jurisprudence in the area and the need to achic've a just and legally. sound system for devermining furure claims. If "prior occupation" is insfead imderstood as a proxy for "commmity conmections to land." then the primary interesis at stake are more clearly revealed. It is then possible to develop a principled and more consistent way of dealing with Aboriginal tirle claims in a way that respects the interests of all innolved.
If y a deux principes divergents sons-jacems it la recommaissance comstitutionnelle de la revendication auto chome dass s. 35(I) dans la Loi constitutionntlls de 1982: le principe Iraditionnel du "promier sur place" " et le principe prospectif de " reconciliation". En examinum le premier principe de plus pres, on constate que plusieurs justifications son possibles pour mettre la revendication d'Aurochone à leipreuve: promousoir lefficacite economique. neurraliser lé droit naturel à la propriété et agir en tan' que procuration pow la protection de l'identite individuelle ou collective. Cependant, ancune de ces justifications ne ripond bien aux detox cas preicedents de jurisprudence dons ce domaine ni d'ailleurs an besoin d'arriver a an sysseme juske ef juridiguement solide de righer les revendications furwes. Si cente notion de "premier sur place " disigne plinot des "liens communataires à la terre ", alors dans ce casla. les imćrèts prioritaires en jeu somt phes clairs. "I serait alors possible de developper une façon motivice et phis consistante de traiter les revendications aufochrones de manière à respecter les intérifs de lous les partis inferesses.

\section{TABle OF CONTENTS}

I. INTRODUCTION ............................ 780

II. HISTORICALIIY-ORIENTED AND FORWARD-LOOKING

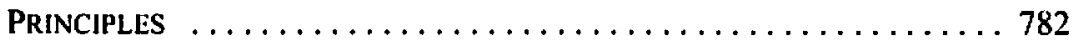

A. Case Law Backdrop ....................... 782

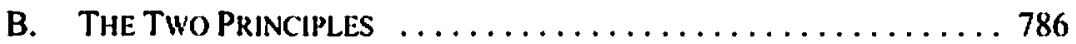

1II. The Normative Forcle of PrIOR OCCUPATION . . . . . . . . . . . 791

A. LIMITS ON THF ForCE OF PRIOR OCCUPATION ........... 791

B. Prior OCCupation as an Efficiency-Promoting

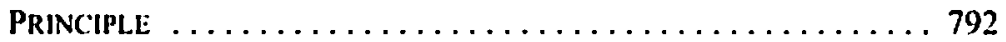

C. Prior Occupation and Natural Rights

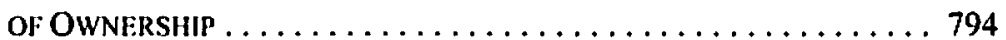

D. Prior OCCUPATION AS ProXy for

IDENTITY PROTECTION

B.A. (Regina), LL.B. (Saskatchewan). B.C.L., M.Phil., D.Pltil. (Oxford). Assistant Prolessor and Associate Dean, Universily of Saskatchewan College of Law. 1 thank Borden Ladner Gervais L.LP for research funding under the BLG Summer Student Resturch Fellowship program. I thank Jill Chapin for research assistance on certain points in the article. I thank the following for helpful comments on a draf version of the article: Jill Chapin. Patricia Famese, Heather Heavin. Tamara Larte, and Barbara von Tigerstron. I also thank the anonymous reviewers for their comments and suggestions. 


\section{Prior OCCUPATION AS ProXy for COMMUNITY}

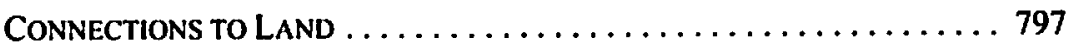

V. CONCLUSION: IMPLICATIONS FOR THE DOCTRINE OF

ABORIGINAL TITLE $\ldots \ldots \ldots \ldots \ldots \ldots \ldots \ldots \ldots \ldots \ldots \ldots . \ldots \ldots$

\section{INTRODUCTION}

The Supreme Court of Canada's modern jurisprudence on Aboriginal title refers to two schismatic principles behind the concept's constitutional recognition. The case law refers both to a historically-oriented principle of Aboriginal title being determined by "prior occupation"' and a forward-looking principle of Aboriginal title being oriented to "reconciliation." Those seeking a textual foundation for this schism in $\mathbf{5} .35$ of the Constitution Act, 1982 might find one in the section's recognition of "existing Aboriginal and treaty rights,"3 something resulting from a last-minute modification in the negotiation process. ${ }^{+}$However, I will argue in this article that the schism reflects, rather, a Supreme Court that has failed to carry out an adequate normative theorization of the principles of Aboriginal title and, thus, inadvertently incorporated two inconsistent elements. ${ }^{5}$ Despite possible initial presumptions that Aboriginal title has been recognized primarily so as to respond to the historical fact that "they were here first," I will argue that the concept of "prior occupation" actually sits uneasily in a normatively theorized account of Aboriginal title. 1

1 See, e.g., Guerirv. Canada, |1984]2 S.C.R. 335 at 376 [Guerin] (referring to Aboriginal title as"a legal right derived from the Indians" historic occupation and possession of their tribal lands"); $R$. v. Van der Peet. (1996] 2 S.C.R. 507 at para. 30 [Van der Peet] (fact of prior occupation mandaling special legal rights), and at para. 119 (dissent also sourcing Aboriginal rights in historic occupation); Delgammukw v. British Columbia, [1997] 3 S.C.R. 1010 at para. 114 [Delgammenw] (referring to force of prior cecupation); Mitchellv. M.N.R., 200I SCC 33, [2001] I S.C.R. 91 ] at para. 10 (describing "the interests of aboriginal peoples arising from their historical occupation and use of the land"); and R. v. Marsiall; R. v. Bernard, 2005 SCC 43, [2005] 2 S.C.R. 220 at para. 129 [Marshall/Bernard] (referring to prior posscssion of land as grounding Aboriginal title).

2 See, e.g., Delgammukw, ibid. at para. 81 (Aburiginal "rights are aimed at the reconciliation of the prior occupation of North America by distinctive aboriginal societies with the assertion of Crown sovereignty over Canadian territory"): Marshall/Bernard. ibid. at para. 39 (envisioning justification process "as a way of reconciling aboriginal interests with the interests of the broader community"); and Mikisen "Cree First Nation v. Canada (Minister of Canadian Heritage), 2005 SCC 69, [2005] 3 S.C.R. 388 at para. I [Mikisew Crec] ("The fundamental objective of the modern law of aboriginal and treaty rights is the reconciliation of aboriginal peoples and non-aboriginal peoples and their respective claims, interests and ambitions"). Constitution Act, 1982, s. 35, being Schedule B to the Canada Act 1982 (U.K.), 1982, c. 11 [emphasis added].

- Sec Michad B. Stein, Canadian Constitutional Renewal, 1968-1981: A Case Study in Imegrative Bargaining, Rescarch Paper No. 27 (Kingston, Ont.: Queen's University Institute of Intergovemmental Relations, 1989) at 71.

5 As I understand his recent. as-yet unpublished comments on listorieal rights and generative rights (e.g., Briun Slattery, "Aboriginal Rights: Where From? Where To?" (Paper presented to the Saskatchewan Institute of Public Policy Moving Towards Justice Conference, Regina, March 2006) (unpublished]). Brian Slattery is on the verge of reading up his earlier recognition of $s$. 35 as containing a "generative constitutional order" (Brian Slattery, "Aboriginal Rights and the Honour of the Crown" (2005) 29 Sup. Ct. L. Rev. (2d) 433 at 436 [Slattery, "Honour of the Crown"|) into one recognizing two kinds of rights, albeit without recognizing the possible inconsistency between the principles behind these two kinds of rights. I certainly respectfully await clarification of his analysis in his future publications on this matter. 
will use that conclusion, in turn, to suggest several changes in the Court's approach to Aboriginal title so as to render this area of Aboriginal rights law more normatively coherent."

A full normative evaluation of Aboriginal rights jurisprudence generally, or of Aboriginal title jurisprudence specifically, would, of course, be an enormous task, one situated against a set of immensely complex social, political, cultural, and historical contexts and involving highly contested claims within moral and political theory. ${ }^{7}$ That sort of project is of immense importance to major policy questions and to the pursuit of justice, and it is well worth pursuing further elsewhere. ${ }^{8}$ However, it is not the project that faces the Supreme Court of Canada in the context of each individual Aboriginal rights case." The Court must decide on a case involving particular litigants against a backdrop of previously decided law that will ground particular expectations by the parties to the case. The Court is accountable to the legal claims that properly arise.

To further the task of normative theory within this adjudicative context. I will endeavour in this article to read Canada's Aboriginal title jurisprudence against something like Ronald Dworkin's adjudicative requirements of "fit" and "soundness." Dworkin oflers an account of adjudication that is, of course, part of ongoing legal theory debates about the proper task of and approach to adjudication. "I draw on Dworkin's account specifically for two reasons. First, it responds specifically to the context of adjudication as a context in which a court is both accountable to legal expectations of the parties and in which a court may seek to render of the law the most just possible system. In so doing, Dworkin offers an account in which the

Seeking to analyze such complex matters within the format ol an article necessarily engages me in a task of partial analysis. To a degree. I analyze prior occupation and $A$ boriginal litle as concepts separable from the range of concepts to which they are connected. In the larger project of which this article is an early par. I hope to approach these concepts in a more thoroughly connected way. However, I would maintain that my argument within this article remains valid without reference to all possible conceptual connections.

1 The application of moral and political theory to the Aboriginal rights contexts has begun to attract significant attention. For an interesting collection of pieces, see Duncan Ivison. Paul Patton \& Will Sanders, eds., Political Theory and the Rights of Indigenous Peoples (Cambridge: Cambridge University Press, 2000). For a seminal monograph in this area, sec Patrick Macklem, Indigenows Difference and the Constitution of Canada (Toronto: Universily of Toronto Press. 2001) (Macklem. Indigenous Difference]. Unfortumalcly, Macklem ultimalcly leaves many questions unanswered and does not go as far in articulating an over-arching theory as one might have hoped.

" I am working on a serles of pieces in this area. See, e.g., Dwight G. Newman. "Theorizing Collective Indigenous Rights" Am. Indian L. Rev. [fortheoming in 2007]: Dwight G. Newman. "You Still Know. Nothin' 'Boul Me: Toward Cross-Cultural Theorizing of Aboriginal Rights" Mc(iill L.J. [forthcoming in 2007]. I am grateful to students in my "Theorizing Aboriginal Rights" seminar for ongoing discussions on a varicty of topics.

- The institutional context in which courts work means that "they cannot, in one decision, hope to achieve what the legislature can in a programme of law reform" (William Lucy. "Adjudication" in Jules Coleman \& Scot Shapiro, eds., The Oxford Handbook of Jurispmedence and Philosophy of law (Ox Ford: Ox ford University Press, 2002) 206 at 220). Lucy is discussing a set of claims contained in Joseph Raz, The Authority of Law: Essoys on Law and Moration (Oxford: Clarendon Pross. 1979) at 201. Although Ras. suggests a sort of discretion in adjudication that goes in some ways beyond what Dworkin would have been ready to conlemplate. Ray. loads onto this discretion a number of institutional factors aboul courts that constrain it significantly. "soundness" in place of "justification," and I follow that usage. 
value of legality may be preserved within the seeking of justice, maintaining both law and normativity and thereby preserving legality as an important element of justice itself. Second, and unsurprisingly given the consonance of such an account with general instincts of the Court, Dworkin's account thus itself contains both historically-oriented and justice-oriented principles. It looks both to the "fit" of a decision with prior legal materials, and to the moral and political theory "soundness" of the legal explanation a court offers. If any account of adjudication can overcome the schism I have identified in the Supreme Court's jurisprudence, one between historically-oriented principles and forward-looking principles, Dworkin's account of adjudication seems a viable possibility. If even it cannot support the Court's jurisprudence as it has developed, this speaks significantly to the need for modifications of that jurisprudence.

In order to do this, in Part II I will flesh out the presence of the two principles in the case law, contextualizing Aboriginal title within Aboriginal rights more generally, and begin to articulate how the two principles stand in potential tension. In Part III, I will hone in on the concept of "prior occupation" to explore several alternative rationales that might be served by the application of a "prior occupation" requirement and to show that each of these alternative rationales would entail other implications that are inconsistent with either the main strands of existing law and/or any normatively sound account of Aboriginal rights. That is, each plausible account of the "prior occupation" requirement ends up failing one or both of the Dworkinian requirements of "fit" and "soundness." In Part IV, I will try to show that "prior occupation" has functioned as a proxy for other more normatively relevant concepts of community (cultural-political) connections to land, and to lay some foundations for an account of Aboriginal title based more directly on community connections to land. In Part V. I will examine the implications for existing tests and legal doctrine, arguing that it is possible to render this legal doctrine more normatively coherent through several specific modifications.

\section{Historicall.y-Oriented and Forivard-Looking Principles}

\section{A. Case law Backdrop}

The Supreme Court's jurisprudence of Aboriginal title, and of Aboriginal rights generally, is set out in a sparser set of cases than those less acquainted with the area might first assume. Aside from some carlier foundations and references, ${ }^{12}$ the $\mathrm{s} .35$ case law on Aboriginal title per.se is developed principally in the two leading cases of Delgamuukw $v$. British Columbia ${ }^{13}$ from 1997 and the recent Marshall/Bernard't decsion released in 2005. One might also add

Sce, e.g., St. Catherine's Milling and lamber Co. v. The Queen (1888), 14 A.C. 46 at 54 (P.C.) [St. Catherine's Milling] (referring to Aboriginal title in lerms of a "personal and usufructuary right"): Calder v. Attorney-Generol of British Columbia, [1973] S.C.R. 313; Baker Lake v. Camadu (Ainister of Indian Affairs and Northern Development). [1980] I F.C. S18 (T.D.): and Guerin, supra note I. Some authors question whether the law in this area has shifted fundamentally beyond the principles of $S$ t. Catherine's Milling: see, e.g., Gordon Christie, “A Colonial Reading of Recent Jurisprudence: Sparrow: Delgammukw and Ilaida Nation" (2005) 23 Windsor Y.B. Access Just. 17.

13 Delgammow, supra nole 1.

It Marshall/Bernard, swpra nole I. 
reference to the 2004 decision in Haida Nation v. British Columbia (Minister of Forests), ${ }^{15}$ but this case was predominantly concerned with obligations of consultation in cases of alleged but unproven Aboriginal title claims and does not yield as much jurisprudence on Aboriginal title itself. ${ }^{16}$

There has been a general tendency amongst academic commentators on the Marshall/ Bernard decision to rapidly assert disagreement with the Court's approach in the case. ${ }^{17}$ Early academic comments on the case by Paul Chartrand, Kent McNeil, and Mark Walters have portrayed it as a sort of step backward from the Supreme Court's evolving receptiveness to Aboriginal claims. ${ }^{18}$ I respect these scholars and their work immensely. However, to the extent that the terms of their critiques of this case suggest a results-based concern with the decision rather than a critique developed at a prior level of legal principle," they endanger their own cause. These authors provide no answer to those on the other side of the issues in the case, ${ }^{20}$ or in Aboriginal rights jurisprudence, when they say that a decision is a good decision if it advances Aboriginal claims and a bad one if it does not. North American legal academia, of course, has long lingered under the sway of critical legal studies scholarship, but legal scholarship founded in ideological attitude ultimately fails to persuade those on the other side of an issue and, worse yet, undermines the fundamental value of legality. "For

2004 SCC 73, [2004] 3 S.C.R. 51I. There are various relatively undeveloped references in other cases as well.

16 It could well be more significant if il establishes s. 35 as containing a "gencrative constilutional order" (Slattery. "Honour of the Crown." supra note 5 at 436) that tends to incorporate but fundamentally reinterpret and revise historical considerations. llowever. the full meaning of the judgment is not yet clear.

17 Paul L.A.H. Charrand. "R. v. Marshall: R. v. Bernard: The Return of the Native" (20106) 55 U.N.B.L.J. 135; Kent MeNeil, "Aboriginal Title and the Supreme Court: What's Happening?" (2006) (69 Sask. L. Rev. 281 [MeNeil, "Aboriginal Title"]: and Mark D. Wallers, "The Morality of Aboriginal Law" (2006) 31 Queen's L.J. 470.

18 See, e.g. Chantrand, ibid. at 140 ("H lolding that Aboriginal laws and customs relating to the use of lands and territories matter only to the extent they mirror those of the English recalls the most extreme form of legal rejection of Aboriginal people, which is the doctrine of terra mullius"); McNcil. "Aboriginal Title," ibid. at 305 (describing MeLachlin C.J.C.'s judgment as "a disappointing retreat from the innovative aspects of ... Delgammen."); and Wallers, ibid. at 472, 517 (describing the case as "forsak [ing] the promise of a iruly intersocietal law" and as a return to one-sided reconciliation). This atlitude towards the decision is not universal; Thomas isaac, for one. seems to see the case as fitting coherently within an evolving body of jurisprudence (Thomas Isaac. Aborigind Tithe (Saskatoon: University of Saskatchewan Native Law Centre, 2006) at 2-3, 58).

14 The language of "retreat" and variations thereon (sec ibid) can be taken as expressing concern about consistency with past law but is as much concemed with whal the authors perceive as being in the interests of Ahoriginal groups. Each of Chartrand, McNeil, and Walters makes clear a certain rooledness in the interests of Aboriginal groups (Chartrand, ibid. at 145 (arguing that the case brings "the spectre of the return of the native, the 'farmyard man' who only matiers when he looks like his master"); McNeil, "Aboriginal Title," ibid. at 308 (explaining what Aboriginal groups shoukd argue in future cases); and Wallers, ibid. at $\mathbf{4 7 3}$ (laking respect for Aboriginal groups as a lundamental value)). To identify this tendency is not necessurily to eriticize it; in our present circunstances, it may well be that this is the most responsible approach for academics to lake. However. there is room for further exploration.

3) Neither Chartrand nor McNeil explores at length the normatise reasons for or against the decision. Walters cexplores moral questions in a limited way w ithin the particular concerns attached lo L.on Fuller's theory of the nule of law.

"C C. Dwight (i. Newman. Book Review ol Aguinst Judicial Activism: The Dectine of Freedom and

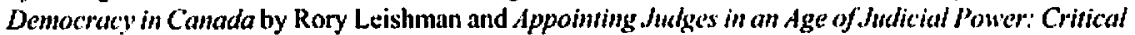
Perspectives from Around the World. Kate Malleson \& Peter H. Russell, eds. (2007) 85 Can. Bar Rev. 
analogous reasons, there needs to be further effort to offer a normative theorization of Canada's Aboriginal tille jurisprudence.

Both on account of the sparseness of the case law on Aboriginal title and on account of its (often not fully acknowledged) close connection with the Supreme Court's Aboriginal rights jurisprudence more broadly, it is worth contextualizing the Aboriginal title case law against that frame. Indeed, the modem Aboriginal title jurisprudence derives directly from Aboriginal rights jurisprudence - despite the existence of an earlier body of case law on Aboriginal title that, in a sense, was shelved once the prospect of fitting Aboriginal title within an Aboriginal rights discourse (rather than a property discourse) emerged. ${ }^{22}$ In Delgamuakw, Lamer C.J.C. describes Aboriginal title as one point on a spectrum of Aboriginal rights and their connection with the land, ${ }^{23}$ and he goes on to engage in what he calls " $[\mathrm{t}]$ he adaptation of the test laid down in Van der Peet to suit claims to title." 24 Thus, the Van der Peet test for Aboriginal rights - "in order to be an aboriginal right an activity must be an element of a practice. custom or tradition integral to the distinctive culture of the aboriginal group claiming the right" ${ }^{25}$ — becomes a three-part test for Aboriginal title:

In order to make out a claim for aboriginal tille, the uboriginal group asserting title must satisfy the following crileria: (i) the land must have been coccupied prior to sovereignty, (ii) if present occupation is relied on as proof of occupation pre-sovereignty, there must be a continuily between present and pre-sovereignty occupation, and (iii) at sovercignty, that occupation must have been exclusive. ${ }^{26}$

Chief Justice Lamer, carlier in the Delgamumkw' judgment, had discussed case law to date on the nature of $A$ boriginal title, alongside a citation of extensive academic authority, to conclude that $A$ boriginal title was not restricted to a protection of practices and traditions. ${ }^{27}$ However, he continued immediately to a sort of conceptual analysis of the sui generis character of Aboriginal title so as to conclude that Aboriginal title is subject to "an inherent limit that lands held pursuant to title cannot be used in a manner that is irreconcilable with the nature of the claimants' attachment to those lands." 28

In developing the Aboriginal title test in Delgamuukw, Lamer C.J.C. makes clear his reliance on McNeil's legal account ${ }^{24}$ of the deep foundations of common law property law to be considered along with the perspectives of Aboriginal legal systems, ${ }^{31}$ something to

433 at $440-42$. Some might respond that all law is inherently subject to contestation and has no place for neutrality. Such a response exemplities the very kind of problem I discuss, ultimately leaving us in an intellectual quagmire and turning litigants into supplicants (cf. Ronald Dworkin. "Judicial Discretion"“ (1963) 60 Joumal of Philosophy 624).

The shift from a property discourse to an Aboriginal rights discourse is cvident even in the recent writing of Kent McNeil, who had played a pioneering role in the property discourse of Aboriginal title; he now indicates that his thinking has moved beyond his earlier writings now that he sees the possible connections of land rights and self-government (McNeil, "Aboriginal Title," supra note 17 at 307 ). Delgammokw. stupro note I at para. 138.

Ibid. at para. 142.

Van der Peet, supra note I at para. 46.

Delgamuakw', supra nole I at para. 143.

Ibid. at para. 123.

Ihid. at para. 125.

Kent MeNeil, Common Law Aboriginal Tille (Ox ford: Clarendon Press, 1989)[McNeil, Conmon Law]. See, e.g., Delgammikw, supra note I at para. 149. 
which he refers particularly in his enunciation of the prior occupation element of the test." To an even greater extent, it becomes apparent that the Aboriginal title test is thought to flow from a purposive development of s. 35. Chief Justice Lamer's reasoning on the second and third branches of the test is based largely on what fits with the purpose of s. 35 while developing the law in a reasonably pragmatic way. ${ }^{32}$

The Supreme Court's development of Aboriginal title jurisprudence, in addition to generalized invocation of academic authority, thus relies on purposive development of legal and normative concepts rather than simply textual and precedent-based application of existing law. This mode of legal reasoning is unsurprising given the Courr's purposive approach to constitutional reasoning generally, ${ }^{33}$ the open-textured nature of $\mathrm{s} .35,{ }^{34}$ and the need for some mode of reasoning about a new constitutional section in the absence of substantial prior authority. Indeed, normative theory has been particularly important to the development of $\mathrm{s} .35$ jurisprudence. ${ }^{35}$

That said, the use of precedent-based reasoning becomes gradually more viable as more s. 35 case law develops. The Court in Marshall/Bernard invokes the Delgamuikw test, ${ }^{\text {, }}$ although McLachlin C.J.C.'s majority judgment also recognizes the need to develop further the standard of occupation demanded within the prior occupation element of the Delgamuukw test. ${ }^{37}$ Against the New Brunswick Court of Appeal's articulation of a lower standard based on some phrases from McNeil's treatise, ${ }^{38}$ McLachlin C.J.C. explores the implications of the nature of Aboriginal title as based on "exclusive" occupation. ${ }^{39}$ To take account of both common law and Aboriginal perspectives, McLachlin C.J.C. develops an account founded on the concept of the way in which the law today can most adequately "translate" pre-sovereignty Aboriginal practices into modem legal rights. ${ }^{.0} \mathrm{Aboriginal}$ title is thus "established by aboriginal practices that indicate possession similar to that associated with title at common law," thus implying a standard of occupation for Aboriginal title purposes well above occasional entry and use. ${ }^{42}$ Justice LeBel, in a concurring judgment, would have favoured a lesser standard of occupation modified to make more room for title

Ibid. at para. 145, citing McNeil, Common Law, supra note 29 at 196.

See, e.g., Delgammukw, ibid. at paras. 153, 159.

See generally /fumter v. Southom, [1984] 2 S.C.R. 145.

On open-textured language, $c$. II.L.A. Itart. The Concept of l.cow, 2d cd. (Oxford: Clarendon Press, 1994) at 128. Hart describes the text of a legal rule as upen-lextured when the text itself leaves an indeterminacy of application. To call s. 35 "open-lextured," then, is arguably understatement in the extreme.

As one measure, consider that Brian Slattery's articles have been cited more frequently in post-1982 constitutional jurisprudence than Peter Hogg's (Peter MeCormick. "The Judges and the Journals: Citation of Periodical Literaturc by the Supreme Court ol 'Canada, 1985-2004"(2004)83 Can. Bar Rev. 633 at 653). That statistic, of course, is deceptive in nol counting citations to books. Ilowever, as another, consider that more than one quarter of the s. 35 cases 10 date (i.e. 102006 ) invoke theoretical writings, most often from Brian Slattery or Kent MeNeil, with most of these writings at least purporting to offer some normalive claims.

Marshall/Bernard, supra note I at para. 40.

lbid. al paras. 40-109.

The Supreme Court glosses the Court of Appeal discussion in ibid. at paras. 42-44.

lbid. al paras. 54-58.

lbid. al para. 48.

Ibid. at para. 54.

lbid. at para. 59. 
claims by nomadic or semi-nomadic Aboriginal groups, ${ }^{43}$ although he was also ready to demand a much more developed evidentiary foundation for Aboriginal title claims. ${ }^{44}$

Against the background of an increasing accumulation of case law that could be applied, it is perhaps easier to be sympathetic to claims like that of Chartrand:

[T]he majority designed an entirely new ... mirror tesı, without apparently relying on or dislinguishing relevant judicial authority. The new lest differs substanlially from both the established judicial views on Aboriginal title and also from the more recent pronouncements in the Court itself, although these have been obiter dicta since the Court has not yet found an Aboriginal title in fact. ${ }^{45}$

There is more force to such a claim in the context of a larger body of case law than there was to concerns by some authors at the time of Van der Peet that the Court had plucked the notion of reconciliation "from thin air." ${ }^{\text {"t6 }}$ However, even today, such an approach neglects the role of theory and normative argument in the Court's development of $s$. 35 jurisprudence.

\section{B. The Two Principi.es}

With this backdrop, it becomes imperative to consider the Court's normative argument and to what degree the Court has adequately normatively theorized its jurisprudence of Aboriginal title. Given the particular attention to the prior occupation requirement in Marshall/Bernard, ${ }^{17}$ this is a particularly interesting focus for discussion. The Court's attention to prior occupation naturally calls for contextualization in the broader principles the Court has cited as residing behind its Aboriginal title test.

The key point to observe about these principles is that the Court's Aboriginal rights jurisprudence generally, and Aboriginal title jurisprudence specifically, has referred to two very different principles as normative sources for the recognition of Aboriginal rights and Aboriginal title. On the one hand, the Court refers to prior occupation as itself a normative foundation for Aboriginal rights and Aboriginal title. Thus, in Van der Peet, Lamer C.J.C. writes that "the doctrine of aboriginal rights exists, and is recognized and affirmed by $s$. 35(1), because of one simple fact: when Europeans arrived in North America, aboriginal peoples were already here, living in communities on the land, and participating in distinctive cultures, as they had done for centuries. ${ }^{248}$ In Delgammukw, Lamer C.J.C. essentially applies this notion: "aboriginal title ... arises from the prior occupation of Canada by aboriginal

4. Ibid. at paras. 126-40.

4t Ibid. at para. 141. Justice LeBel insightfully indicated the possible need to consider altemative procedural medianisms for the assessment of evidence on Aboriginal title claims, which have toos frequently ariscn in summary conviction proceedings probably not ideally suited to such complex issues: ibid. at paras. 142-44.

4. Chartrand, sipro note 17 at 139.

to Russell Lawrence Barsh \& James Youngblood Henderson, "The Suprente Court's Van der Peet Trilogy: Naive Imperialism and Ropes of Sund" (1997) 42 MeCiill L.J. 993 at 999.

". Marshall/Bernard, supra note $\mathrm{I}$.

4s Van der Peet, supra note I at para. 30 [emphasis in original]; L'Heureux-Dube J.'s separate opinion similarly stales (at para. 119) that "the source of these rights is the historic occupation and use of ancestral lands by thi natives." 
peoples." ${ }^{+4}$ And Marshall/Bernard maintains the same strand of normative principle: "As with all aboriginal rights protected by s. 35(1) of the Constitution Act, 1982, aboriginal title arises from the prior possession of land and the prior social organization and distinctive cultures of aboriginal peoples on that land." ${ }^{\circ 0}$ These passages thus suggest a normative foundation grounded in historical fact that is claimed to have present implications for the just treatment of Aboriginal groups. ${ }^{51}$

On the other hand, the Court refers to s. 35 as geared towards secking "reconciliation." The language of what is to be reconciled has somewhat shifted over the yeurs, with the most recent shift being from the prior existence of Aboriginal societies and the assertion of Crown sovereignty to the interests of Aboriginal groups and the interests of Canada. ${ }^{32}$ In one sense, the modern language of reconciliation has become even more focused on future-looking objectives rather than on a sort of forward-looking but historically-rooted reconciliation in some of the earlier case law. ${ }^{53}$

Thus, on the earlier conception in Van der Peet, Lamer C.J.C. pronounces the purpose of s. 35 to be "the reconciliation of the pre-existence of aboriginal societies with the sovereignty of the Crown." "St Chief Justice Lamer reinvokes this purpose in Delgamuukw: "I explained in Van der Peet that those [s. 35] rights are aimed at the reconciliation of the prior occupation of North America by distinctive aboriginal societies with the assertion of Crown sovereignty over Canadian territory." $\$$ The purpose of reconciliation then also becomes an interpretive lens through which the translation of Van der Peet is to apply to Aboriginal title, with Lamer C.J.C using the claim that "the purpose of $\mathrm{s.} \mathrm{35(1)}$ is to reconcile the prior presence of aboriginal peoples in North America with the assertion of Crown sovereignty" to begin his section on the test for Aboriginal title. ${ }^{36}$

One sees the later conception of reconciliation in the Court's more recent reasoning in Marshall/Bernard. Here, McLachlin C.J.C. introduces the purpose of reconciliation as bearing on the process of "translating"" historic activity or occupancy into modern legal right: "The process begins by examining the nature and extent of the pre-sovereignty aboriginal practice in question. It goes on to seek a corresponding common law right. In this way, the process determines the nature and extent of the modern right and reconciles the

Delgamuthk, srtpra note I at para. 114.

Marshall/Bernard, supro nole I at para. 129.

If one attempted to read the passages as concerned with the continuity of politically sovereign jurisdiction of Aboriginal peoples, one would still not escape the claimed imponance of historical fact inherent in these arguments.

I have examined this shift at length elsewhere. See Dwight G. Newman, "-Reconciliation: Legal Concept(s) and Faces of Justice" in Ian Peach \& John Whyte, cds., Moving Towards .hrstice (Suskatoon: Purich, fortheoming) [Newman, "Rceonciliation"].

See my discussion in ibid.

Van der Peet, supra note I al para. 31.

Delgamuskw, supra note 1 at para. 81.

lbid. at para. 141. In an interesting but isolated statement. the Court in Takn River Tlingir described s. 35(1) as "the ultimate reconciliation of prior Aboriginal oceupation with de facto Crown sovereignty": (Taku River Tlingit First Nation v. Brinish Columbia (Project Assessment Director), 2004 SCC 74, [2004] 3 S.C.R. 550 at para. 42 [Taku River Tlingit]).

This aspect of McLachlin C.J.C.'s approach has been effectively criticized. See especially Walters, supra note 17 at 517 (identifying its one-sided nature). 
aboriginal and European perspectives. ${ }^{\text {} 88}$ This reference to reconciliation was actually her second reconciliation reference in the case. She had also earlier stated that the $R$. $v$. Sparrow" justification process could be seen "as a way of reconciling aboriginal interests with the interests of the broader community." ${ }^{60}$ Although the Court offers no full account of what reconciliation means, there can be no doubting the Court's identification of a forwardlooking reconciliatory principle in s. 35. As Binnie J. has put it most recently: "The fundamental objective of the modern law of aboriginal and treaty rights is the reconciliation of aboriginal peoples and non-aboriginal peoples and their respective claims, interests and ambitions." ${ }^{\circ 1}$

Although some statements from the Court may, even if indirectly, refer to both purposes simultaneously, ${ }^{62}$ they are frequently independently invoked. This is unsurprising, for the Court implicitly invokes significantly different normative principles that, at the very least, cannot be taken as inherently compatible. Although some academic writing seems to presume that something like prior occupation can be incorporated into a mélange with a variety of other normative bases, ${ }^{63}$ there is real reason to interrogate the principled interaction of a historically-based rationale that looks backward in time in its articulation of what justice demands with a future-based rationale that looks forward in time in its articulation of what justice and/or the mutual flourishing of communities demand. ${ }^{64}$

Recognizing the simultaneous presence of a historically-oriented rationale and a forwardlooking rationale does not lead to any automatic conclusion of their incompatibility. Broader debates about reconciliation and peace in other contexts sometimes treat the resolution of historic injustices as essential to the achievement of forward-looking goals. ${ }^{65}$ It may be that the normative principles of prior occupation and of reconciliation are intermeshed in this way. However, any such conclusion demands significantly more analysis; just as this argument calls into question an automatic conclusion of incompatibility, it would be similarly inappropriate to assume compatibility."

These tensions do not arise uniquely in the Aboriginal rights context, but relate to a broader debate about the relationship between process-based justice (which attaches

ss Marshall/Remard, stipra nole I at para. 51.

\$4 [1990] I S.C.R. 1075.

so Marshall/Bernard, sippra nole 1 at para. 39.

ol Mikisew Cree, supra notc 2 at para. 1.

6. Sec, c.g. Delgamumku, supra note I at para. 145 ("from a theoretical standpoint, aboriginal title arises out of prior occupation of the land by aboriginal peoples and out of the relationship between the common law and pre-existing systems of aboriginal law").

63 The ability to mix together different sorts of bases is a dominant undertone to Macklem, Indigenous Difference, supra note 7. Cf. also S. James Anaya, "Maya Aboriginal Land and Resource Rights and the Conflict Over Logging in Southern Belize" (1998) I Yale Human Rts. \& Dev. L.J. 17 at 68-69.

Some might question why such a blend is problematic; after all, all law has past, present, and future, and adjudication presumably makes choices between them on a regular basis. However, the difficulty is in the potentially very different implications of a historical rationale and a future-based rationale for Atoriginal rights. Which prevails has very significant consequences.

65 Dwight G. Newman, "The Rome Statute, Some Reservations Conceming Amnesties, and a Distributive Problem" (2005) 20 Am. U. Int'I L. Rev. 293 at 295-96 (jdentilying such claims as widespread amongst human rights advocates). 
significance to historical rights and transfers) and end-state-based justice (which attaches significance to present concerns like ongoing equality of resources). ${ }^{67}$ The two kinds of theories were, at one stage in the debates, epitomized by the accounts of Robert Nozick, who advanced a process-based theory of property rights based on just acquisitions and transfers, ${ }^{6.8}$ and John Rawls, who advanced an end-state-based theory of justice concerned with equality of resources in present circumstances. ${ }^{69}$ The latter argument, a concern for end-state justice, has arguably had more influence among political theorists and, indeed, has become a central tenet of liberalism. ${ }^{70}$

Despite how it might appear, recognizing the primary normative force of one or the other sort of concern does not have automatic implications. In particular, returning to the Aboriginal rights context, even though the authors of the 1969 White Paper ${ }^{71}$ were no doubt working within an end-state-based approach, ${ }^{72}$ an end-state-based theory applied to Aboriginal rights need not resemble the White Paper approach. ${ }^{3}$ Will Kymlicka's monumental writings have made this point clear. Kymlicka adheres to an end-state-based approach, reflected both in his general reasoning based on equality of resources ${ }^{74}$ and in his specific conclusion that "it is far from clear why it matters who first acquired a piece of land." At the same time, within an equality of resources argument, Kymlicka has been centrally concerned with arguing for the protection of certain cultural rights for Aboriginal groups on the basis that they otherwise face unequal costs in maintaining their cultures. ${ }^{76}$ The result is an acceptance of an array of policies very much attuned to modern Aboriginal claims." $^{\text {"n }}$

Cf. Will Kymlicka, Comtemporany Political Philosophy: An Introduction, 2d ed. (New York: Oxford University Press, 2002) at 112-13 [Kymlicka. Contemporan Political Philosophy]. Robert Nozick, Anarchy: State, and Utopia (New York: Basic Books, 1974).

69 John Rawls, A Theon of Jistice (Cambridge, Mass.: Belknap Press, 1971).

in See Kymlicka, Contemporary Political Philosophy, supra note 67 at 53-97.

1. Canada, Statement of the Government of Camada on Indian Policy, 1969 (Ottawa: Department of Indian Affairs and Northern Development, 1969) [W'hite Paper].

7. Prime Minister Trudeau succinclly explained the philosophical foundations of the White Paper as concerned with current individual equality and with justice in present times. For a concise discussion. see Alan C. Cairns, Cirizens Plus: Aboriginal Peoples and the Comadian State (Vancouver: UBC Press, 2000) at 51-53.

I raise the While Paper specifically to make this point because of the very negative connotations of the White Paper. End-state-based theorics can be dramatically different than the White Paper. One could engage in an interesting task of characterizing the philosophical principles behind other key documents on Aboriginal rights. This would not always be easy. The Report of the Royal Commission on Aboriginal Peoples (Ottawa: Supply and Services Canada, 1996) [Report]. for instance, has extensive references to "reconciliation" and thus might appear fonward-looking. However, some interpretations of its reconciliation discussion see it ats an interpretation of reconciliation oriented to healing past wrongs (Caims, ibid at 86), and the Report also lends to stress cultural survival over cconomic opportunily (Cairns, ibid. at 128-30), both polentially manifesting a concomilant historical orientution.

7 Sec Will Kymlicka. Liberalism. Commumin and Culuure (Oxford: Clarendon Press, 1989) at 182-205.

" lbid. at 158, n. 4.

io lbid. at 182-205.

"See, e.g., Will Kymlicka, Multicultural Citizenship: A Liberal Theony of Minority Rights (Oxford: Clarendon Press, 1995) at 38-40 (showing, unusually amongst most Canadian commentators, even some openness to the idea of Aboriginal self-govemment not subject to the Charter). 
In a stream of provocative recent work with direct implications for the Aboriginal title context that scholars have thus far seemingly failed to answer, ${ }^{78}$ Jeremy Waldron has called into question whether process-based justice can possibly trump end-state-based justice. ${ }^{74} \mathrm{As}$ put in his 2002 version of the argument, offered implicitly in the Canadian context, ${ }^{80}$ Waldron argues that the normative rationales of process-based justice themselves run counter to any extreme claims for historically-based principles. In particular, he argues that if circumstances affect which acquisitions are and are not just, then they also affect which is or is not today an unjust action against justly held property, with the implication that changed circumstances can affect whether continuing adverse possession is an injustice or not. ${ }^{81}$

An example may make the point clearer. If, for instance, a particular group had historically seized a waterhole from another group out of pure greed and all other waterholes in the area had subsequently dried up, the seizing group might retain a justice-based right to share that waterhole based on the principles that would have compelled the sharing of it had they never seized it. ${ }^{82}$ Even without the more artificial elements of this stylized example, the general point is that an adverse possessor may acquire certain claims in justice, perhaps due simply to settled expectations. ${ }^{83}$ Waldron's argument implies that historically-based principles cannot fully trump end-state-based concerns.

The appropriate interaction of historically-oriented and forward-looking principles is complex. The distinction is analogous to the distinction between process-based and end-statebased theories of justice. However, it is not identical. One could conceivably have a processbased theory of justice for forward-looking reasons, as, for instance, one could imagine as a possible interpretation of a doctrine founded on negotiation and consultation. There would thus be room to explore further possibilities, and Canadian scholars writing on Aboriginal rights questions have untortunately paid limited attention to such issues when they are, in fact, at the very heart of any appropriate normative understanding of the emerging Supreme Court doctrine. That said, it is possible to advance this understanding by undertaking a narrower task concerned with the normative force of prior occupation. Leaving a more complete exegesis of the forward-looking principle of "reconciliation" to elsewhere, ${ }^{84}$ the

:* Dale lumer ofters a one-line response with a few more lines in a footnole: Dale Tumer. Thix Is Nor a Peace Pipe: Towards a Critical Indigenoms Philosophy. (Toronto: University of Toronto Press, 2006) at 68-69, 154, n. 36. Duncin Ivison also offers a bricf response: Duncan Ivison, Postcolonikd Liberalism (Cambridge: Cambridge University Press, 2002) at 99-101. Janna Thompson addresses bolh related themes and Waldron's argument at signilicantly more length: Janna Thompson, Taking Responsibiling for the Past: Reparation and Historical Injustice (Cambridge: Polity, 2002). But none of these authors provides any sort of definitive answer to Waldron's argument.

iq See especially Jeremy Waldron, "Superseding Historic injustice" (1992) 103 Ethics 4; Jeremy Waldron. "Historic Injutice: Its Remembrance and Supersession" in Graham Oddic \& Roy W. Perrett, eds., Justice, Ethics, and New Zealoud Srcient (Auckland: Oxford University Press, 1992) 139 [Waldon. "Historic Injustice"]; Jercıny Waldron, "Redressing Histuric Injustice"(2002) 52 U.T.L.J. I35 [Waldron, "Redressing"]; and Jeremy Waldron. "Settlement. Return. ankl the Supersession Thesis" (20)4) 5 Theoretical Inq. L. 237.

Ihid. al 152-53.

lbid. at 151-52.

Cf. Bruce Ziff, Principles of Property Law, 2d ed. (Toronto: Carswell, 1996) at 120-21.

See Newman, "Reconciliation," supra note 52. 
concept of "prior occupation" warrants particular attention. Does a normative theorization of prior occupation yicld anything for the issues that have arisen?

\section{The Normative Force of Prior OCCUPation}

\section{A. Limits on the force of Prior OCCupation}

The historical fact that Aboriginal groups were in prior occupation of substantial parts of what was to become Canada prior to European settlement may seem intuitively to have immediate normative force for the presently just ownership of those areas. The notion that "they were here first" has an intuitive moral resonance. That intuition may have been weakened already by Waldron's arguments in the last section. ${ }^{85}$ Indeed, interestingly, an author who has carried out one of the most prominent projects endeavouring to normatively theorize Aboriginal rights claims secks to rely on prior occupation as a normative principle even after admitting signilicant doubts about the normative force behind it. ${ }^{\mathrm{s}}$ Patrick Macklem takes on board some of the critiques of the normative significance of prior occupancy for just allocations of property made by the likes of Will Kymlicka and Jeremy Waldron, ${ }^{87}$ but he then argues essentially that so long as prior occupation is significant in law for others, there is unjust discrimination if Aboriginal groups' prior occupation is not recognized and given legal effect. ${ }^{\mathrm{k}}$

However, nobody would reasonably maintain that prior occupation has unlimited, allpervasive normative force for modern ownership and that equality then demands its application as such. The present moral implications of historical injustice are complex in general terms. ${ }^{x y}$ and no less so in the specific context of Aboriginal title claims. For instance, in the southwestern United States, the historical fact that the Hopi were in prior occupation of lands that a group of what Canadians would now call Dene (and Americans call Athabaskans) moved and took from them, in the process of becoming the group now called the Navajo, ${ }^{90}$ does not have any automatic normative implication that all such lands must today be returned to the Hopi. Actually, the Hopi do in fact make claims against the Navajo, particularly concerning ownership of certain sacred sites, ${ }^{11}$ but it remains obvious that the Navajo should not lose all their land on the basis of prior historic occupation by the Hopi.

Sec also Waldron. "Historic Injuslice." stpra note 79 at 167 : "We were here first." These simplicilies have always been unpleasant ways of denying present aspirations or resisting current claims of need. They become no more pleasant, and in the end no more persuasive. by being assuciated with respect for aboriginal peoples or revulsion from the violence and expropriation that have disfigured our history." Macklem, Indigenows Difference, swpra note 7 at 78-85. He had previously acknowledged doubis about the normative relevance of prior occupancy to sovereignly claims: Patrick Macklem. "Distributing Sovercignty: Indian Nations and Equality of Peoples" (1993) +5 Stan. L. Rev. 1311 al 1327-35. Macklem. Indigenous Difference', ibid.

Ibid. at 85.

See generally Eric A. Posner \& Adrian Vermeule, "Reparations for Slavery and Oher Ilistorieal Injustices" (2003) 103 Colum. L. Rev. 689. Sec also Thompson, supra note 78. identification of cultural exchange that took place between the groups. Sece, e. g. Janct Catherine Berlo \& Ruth B. Phillips, Native North American Are (Oxlord: Oxford University Press, 1998) all (10-61. Sec, e.g. Michacl l: Brown, Who Oums Native Cirlewe? (Cambridge. Mass.: I Harvard University Press, 2003) at $19-20$. 
If readers prefer fully Canadian examples, ${ }^{92}$ modern accounts of Aboriginal history in Canada attuned to the role of Aboriginal persons and groups as historical actors (rather than entirely passive recipients of colonialism) cite various instances in which Aboriginal groups took territories that had been previously occupied by other groups, both before and after the assertion of Crown sovereignty over the territories involved. ${ }^{93}$ Recognizing that historical fact does not say anything critical of any Aboriginal group but does appropriately highlight some of the complexity to the appropriate limits on the legal and normative force of prior occupancy.

Within the Canadian legal system, prior occupation has some, but not unlimited, legal force. Indeed, the courts develop limits on the force of prior occupation based on the rationales behind its relevance to title. To examine rationales for the legal force of possession and to examine their implications for the force of possession in the Aboriginal title context is not to treat Aboriginal groups unequally, but equally. Three plausible rationales for the force of prior occupation arise from the outset, and examining them has the potential to shed more light on the normative force of prior occupation in the Aboriginal title context.

\section{B. Prior Occupation as an Efficifncy-Promoting Principle}

McNeil's argument for the force of possession in the real property context establishes only that de facto possession (analogous in relevant respects to occupation) grounds legal possession, and any title claim is only more remotely inferential from this conclusion," showing at once the limited nature of the force of possession. Part of McNeil's argument begins from analogies to possession in the personal property context. ${ }^{95}$ These cases - recall the sorts of cases concerning the necessary level of control over a fox, ${ }^{46}$ a school of fish, ${ }^{97}$ or a lost bracelet ${ }^{98}$ - raise at once the first sort of rationale.

This first possible rationale is that a rule according ownership based on first possession reflects a concern for economic efficiency. The personal property cases illustrate, at once, different dimensions of this rationale. Pierson v. Posit) was an 1805 case concerning ownership of the fox that Post was chasing with his hounds across unowned land when

The American example is simply in suppon of a theoretical point, and there is no inherent reason to prefer examples from one country or another on points of normative theory. Indeed, there maly be much to be gained from examples in the United States and other countries in that reference to them expands the range of examples that have becn written about.

Sec, e.g. Arthur J. Ray, I Have Lived Here Since the World Began: An Illustrated History of Canada's Native People, rev. ed. (Toronto: Key Porter Books, 2005) at 53-54, 79, 91 . Of course, the concept of "prior occupation" need not be considered in simple physical terms. One can think of prior occupation in richer terms as a reference to a form of legal pluralism and implicit reference to the ownership of particular territories according to the prior-existing legal orders of Aboriginal communitics. Sec James Youngblood Henderson, First Nations Jurisprudence and Aboriginal Rights: Defining the Just Society (Saskaloon: University of Saskatchewan Native Law Centre, 2006) at 119-23. However, such a conception of prior occupation does not fundamentally alter what is at stake; a claim to land based on prior acquisition must be considered as against a claim based on present circumstances. McNeil, Common Law. supra note 29 at 73-78.

Ibid. at 11.

Pierson v. Post, 3 Cai. R. 175 (N.Y. Sup. Ct. 1805).

Young v. Hichens (1844), 6 Q.B. 606, 115 E.R. 228.

Parker v. British Ainway:s Board. [1982] I All E.R. 834 (H.L.).

Supra nole 96. 
Pierson stepped in and took it. The New York Supreme Court actually split in the case, and the differing arguments of the majority and dissent, on one reading, manifest the different facets of the economic efficiency rationale. ${ }^{1(x)}$ The majority aspires to certainty and order and sees a rule alloting property ownership based on first possession as contributing to these objectives. The dissent is ready to look to broader economic efficiency in the specific circumstances, thus rendering ownership granted in response to first possession as a reward for the useful labour of taking possession. Characterizing the personal property cases in this line more broadly. June Carbone equivalently describes how "the outcomes in the cases reflect a balance between the exient of the investment and the importance of property rights in encouraging it weighed against the transaction costs involved in policing the rights accorded." 101 There are two main dimensions to a possible economic efficiency rationale behind a rule according ownership based on first possession. First, it might promote economically useful activities to bring unowned property into possession. Second, it might simply be a clear rule in circumstances where a clear, easily applicable rule itself adds economic valuc. ${ }^{102}$

Economic efficiency rationales, however, are at least potentially unpromising for Aboriginal title. If the rationale for ownership allotted based on first possession is economic efficiency, limits on the force of first possession will correspond to that rationale. Such a prospect conceivably threatens to reawaken the very kind of economic arguments that have historically been associated with colonialist dispossession of Aboriginal groups: claims that dispossession was legitimate, at least in part, because of relatively less economically efficient use of the land by Aboriginal groups than by prospective scttlers. ${ }^{103}$

One could, of course, develop a richer set of economic efficiency arguments more attentive to the ways in which one would today recognize greater value in Aboriginal land use. Indeed, some economic theorists might seck to develop a thoroughgoing analysis of "the comparative economic efficiency of different proposed uses of the land, some kind of economic analysis of the effects of dispossession (which could count the cosis of cultural displacement and the like), and so on. It might nonetheless remain the case that, within this line of argument, less economically productive uses of land could ground limits on the scope

Neither the majority nor the dissent is explicit in its normative analysis. Richard Epstein sees matters more blunlly, writing of the judgments in the case that "|t|he large question - why is first possession sufficient to support a claim for ownership - received no consideration alt all": Richard A. Fpstein, "Posstssion as the Root of Title" (1979) 13 Ga. L. Rev. 1221 at 1225.

101 June Carbone, "Back to the Future: Intellectual Property and the Rediscovery of Property Rights - and Wrongs" (2002) 46 St. Louis U.L.J. 629 at 639 [footnotes omilted].

II: Cf. also Carol M. Rose, Property and Perstuasion: Essans on the Histony. Theon: and Rhetoric of Ownership (Boulder, Colo.: Westview Press, 1994) at 16 (discussing how clarity of propenty rights enhances the value of property).

103 See, e.g., John Locke, The Second Treatise of Govermment. Thomas P. Peardon, ed. (Indianapolis: Bobbs-Merrill, 1952) sec. 25 and Jeremy Bemtham. The Theory ofl.egistation, C.K. Ogden, ed. (London: Routledge \& Kegan Paul L.td. 1931) at 118. (hief Justice Marshall dodged the argument in Johnson 1: W'Imtosh, 21 U.S. 543 at 588 (1823) ("We will not enter into the controversy, whether agriculturalists, merchants. and manufacturers, have a right, on abstract principles, to expel hunters from the territory they possess"). The colonialist argumentation was of course not confined to economic basses. For a fascinating examnination of the range of philosophical claims at stake in the renowned debate at Vallidolad, called by the Spanish king to discuss the morality of Spanish colonial policy, sec Lewis Hanke, Aristolle and the American Indians: A Sudy in Race Prejudice in the Modern World (London: Hollis \& Carter, 1959). 
of $A$ boriginal title. If the rationale behind the force granted to prior occupation is an economic rationale, the force of prior occupation is subject to economic-based limits. Economically inefficient land usage would potentially awaken such limits, subject to the inefficiency outweighing the possible value of the clear rule that first occupation might offer and the costs of dispossession. Especially given the kinds of proof that could be given of different sorts of economic costs and bencfits, it would appear possible that Aboriginal title claims would be subjected to signilicant and normatively unacceptable limits based on this alleged rationale for a first possession rule.

Perhaps even more definitively, any economic efficiency rationale would seem at odds with the fundamental jurisprudential principles present in the existing Aboriginal title case law. To take one central example, the "inherent limit that lands held pursuant to title cannot be used in a manner that is irreconcilable with the nature of the claimants' attachment to those lands"10t sits uneasily with any economic efficiency rationale for normative significance to "first attachment" to the lands. This sort of inherent limit constrains the possible uses of lands held under Aboriginal title in a manner that may prevent an Aboriginal group from making the most economically efficient use of particular lands in the modern context. It might seem crass to say, but "paving paradise" may be the preferred and cconomically efticient choice of certain groups with respect to certain parts of the lands they would hold subject to Aboriginal title. and the inherent limit doctrine is thus at odds with an economic efficiency rationale. Both normative soundness and legal fit with existing doctrine are doubtful with an economic efficiency rationale.

\section{Prior OCCUPATION AND NATURAL Rights OF OWNERShIP}

A second plausible rationale for ownership based on prior occupation would maintain that first occupation has an inherent, rather than instrumental, importance. The claim on this rationale would be that lirst occupation grounds a natural right of ownership over what is occupied, on the basis that an act of just acquisition, carried out through occupation, grounds just ownership. ${ }^{105}$ Any such rationale posits the notion of a just acquisition that grounds future ownership claims and would also need to presume a theory of just transfers, ${ }^{106}$ thus rendering property claims into those fitting a set of procedural requirements. ${ }^{107}$ There are theorists who consistently maintain such an account, notably Robert Nozick, ${ }^{108}$ but few theorists are ready to accept all the implications of such accounts, which would seemingly include a rejection of any redistributive activity by the state other than that measured so as to undo historical injustices. ${ }^{\text {the }}$ For that matter, such implications may well not be in the interests of Aboriginal groups. In a significant number of cases, their members may well benelit from, for instance, social policies designed to address the interests of those in poverty, not all of which might be supported under accounts of rectification of historic

\footnotetext{
104 Defgammokw, sippol nole I at para. 125.

14s Cf David Lyons. "The New Indian Claims and Original Rights to Land" (1977) 4 Social Theory \& Practice 249 at 253.

ims Secibid.

111. Se generally Nosick, supra note 68 .

los lbid.

INo See generally Kymlicka, Contemporary Political Philosophly, supra note 67 al 111-13, 156-58.
} 
injustices. ${ }^{110}$ The normative soundness of this rationale for the implications of first occupation is at least questionable.

One might add that this sort of rationale also does not fit central features of the law of Aboriginal title. It is perhaps consistent with the inherent limit on Aboriginal title with which the economic efficiency rationale was so dramatically inconsistent." "If one were prepared to break up the bundle of property rights and say that a first possessor justly acquired only those property rights short of full title that the first possessor had fully acquired in an object or land, then it would become possible to explain the inherent linit on that basis. However, the account would struggle more with other central features of the doctrine of Aboriginal title. For instance, this account would clearly root claims in first occupation per se rather than in prior occupation, driving a history-unraveling process extending beyond the moments in time established within the Aboriginal title and Aboriginal rights jurisprudence ${ }^{1 / 2}$ and denying the possibility of something like Métis rights claims unless they arose on what was previously rerra nulliws, land unoccupied prior to Métis occupation. ${ }^{113}$

\section{Prior Occupation as Proxy for Identity Protection}

A third rationale for ownership based on prior occupation would be that prior occupation actually functions as a sort of proxy for the protection of an individual's or group's identity. ${ }^{1 / 4}$ On this rationale, an act of prior occupation is not important solely on the basis that it might have been an acquisition but because the fact of historical occupation tends to identify ownership linked closely to the personal identity of an individual or the community identity of a group. That an individual may maintain ownership over objects over which he or she established prior occupation is important, then, because to recognize this ownership recognizes his or her agency in taking possession of these objects and, thus, an aspect of his or her identity. ${ }^{115}$ To refuse to recognize this ownership would fail to recognize the agency of the individual and undermine recognition of his or her identity. "1th Obviously, in some

110) If redistribution of land can be one policy addressing Aboriginal poverty, it is not the only one. The problem on this rationale is that historically-based land transfers will be the only morally pernissible anti-poverty policy.

III Sece supro note 104 and accompanying text.

11: Sec Van der Pe'el. stupra note 1 at para. 60 (identifying the moment of contact as of particular significance lor Aboriginal rights generally) and Defgammown. supro note I at para. 142 (ideutilying the moment of assertion ol (rown sovereignty as of particular signilicance for $A$ boriginal litle). Cf. R. v. Powky. 2003 SCC 43. [2003] 2 S.C.R. 207 at para. 17 [Powley] ("the inclusion of the Métis in s. 35 is not traceable to their pre-contact occupation of Canidian territory"). To a degree, the Supreme Court case law has read Métis rights as if they will have to be explained in some different normative framework ( $e$ g., ibid.), but there must be some way of reading the rights of $s .35$ in a manner that makes s. 35 a coherent whole.

114 Cf. Margaret Janc Radin, "Property and Personhood" (1982) 34 Stan. L. Rev. 957 at 960 (portraying property as within the scope of one"s personhood). One could also consider whether prior occupation could act as a proxy for something else, such as lor historic injustices involved in dispossession (e.g., in the modes of dispessession). However, only something like a connection to identity really explains the nature of $A$ horiginal title as a property claim thal will in some instances seck restitution of specific lands.

115 Jim Harris would see something like the way I have explained this as a slighlly different rationale from what Radin, ibid, intended within her theory. Ile argues that if one is to support rights to transfer property, one needs to see property rights as helping constitute individual autonomy more than seeing property itself as constituting individuals' persomalities. See J. W. Harris, Propery and Justice (Oxlord: Clarendon Press, 1996) at 221-22.

116 Unlike Harris, ibid. I would see agency itself as integrally part of one's identity. 
instances, an individual will have agreed to sell an object, and recognizing his or her agency interests and identity then implies recognizing the sale. ${ }^{117}$ (And there may be other ways in which an individual's identity ceases to be bound with a particular object.) Similarly, the community identity of a group that took first occupation of an object or land will tend to be bound with its ongoing ownership of that object or land unless some circumstance has changed such that it has ceased to be so bound. ${ }^{118}$

This third kind of rationale would not imply that prior occupation was always the sole determinant of with whose identity an object was most closely bound. Although Margaret Jane Radin's personality theory of property, ${ }^{119}$ from which this third rationale implicitly builds, is often cited by academics in quick support of repatriation claims for cultural property, ${ }^{120}$ concem for prior occupation as proxy for identity demands careful attention to what property rights foster a flourishing community identity. ${ }^{121}$ Moreover, it calls for attention to possible competition between the claims of different groups that may both or all have community connections to particular land or a particular object of cultural property. ${ }^{122}$ In some cases, the appropriate resolution may in fact correspond to first possession; for instance, it might be the case that the Elgin Marbles are more centrally relevant to the cultural identity of the Greeks than of an appropriately flourishing community identity in Britain. ${ }^{123}$ On the other hand, it is far from clear that making historic determinations concerning first occupation of Jerusalem would have anything to do with assessing the claims of different religious-cultural groups concerning their community relationship with the holy land. Different groups other than any historic first possessor per se may have developed deep community connections with particular objects or lands.

This kind of account, aligned with modern personhood theories of property, fits well with the kind of explanations given of the scope of Aboriginal title. First, this account would explain the inherent limit on the scope of Aboriginal title discussed in relation to the other two rationales. ${ }^{124}$ On this account, an Aboriginal group does not have a claim to make use of lands held under Aboriginal title for a purpose irreconcilable with the nature of historical use grounding title because the rationale for the concept of Aboriginal title is concerned with community connections to the land and the historic uses of the land are a proxy for the ways in which the community was spiritually and culturally connected to the land. There is no basis for claiming rights to use lands held under Aboriginal title for uses inconsistent with the Aboriginal cultural and spiritual connections to the land.

At the same time, this sort of account looks to what is actually centrally connected to the community identity of a group, looking not to some historical mist of time but to what can be established as rights closely connected to that community identity. So, as in the central

On the fact that such recognition means that justice in the property context must have some historical dimensions, of. Lyons, supra note 105 at 254. to Cultural Property" (2005) 80 N.Y.U. L. Rev. 1207 at 1208, 1220-21.

lbid. al 1224-25.

Ibid.

lbid. at 1234-36.

Ste text accompanying supro notes 104, 111-13. 
elements of current Supreme Court doctrine incorporating a specific time reference into the test for Aboriginal title, ${ }^{12 s}$ prior occupation is more significant than first occupation per se. There is, within the account, no particular reason to go back to the historical mists of time so much as to look for a time frame that allows for a reasonable assessment of community connections to land. Moreover, there is within the account the possibility of a different community establishing a more modern community connection with particular lands, something consistent with the prospect of Canadian law recognizing Métis rights in respect of certain lands. ${ }^{26}$

This account offers the prospect of an interpretation of first occupation that somehow coherently unites a historically-oriented principle and the notion of reconciliation with communities lacking the same historical connections with lands but having other sorts of connections with these lands. ${ }^{127}$ It explains how Aboriginal title can be fitted into a continuum of Aboriginal rights claims partly by transforming it from a property-oriented claim to a claim based on the cultural-political nature of communities. In so doing, it comes closest to the evolving normative accounts that sec Aboriginal title as important in cultural and political senses, but that have not received attention within narrow property-based accounts. ${ }^{128}$ It affirms Aboriginal identity and responds to the sorts of spiritual explanations that many Aboriginal theorists have themselves given as residing behind modern claims for Aboriginal title. ${ }^{124}$

This account, unlike the others examined, leads to reasonably sound results at a normative level and to results reasonably consistent with certain central features of the modern jurisprudence of Aboriginal title. This account. however, would tend to lead to modification of the prior occupation element of the test itself. On this account, the prior occupation itself is not normatively significant, but rather that which prior occupation represents. Prior occupation serves as a sort of proxy for community connections to land.

\section{Prior Occupation as Proxy for COMmunity Connections to LAND}

The preferable account of prior occupation reached in the last section leads to an undermining of the force of prior occupation per se. Why then does it still figure so prominently in the case law, even gaining stature in the most recent decision? By examining the role of prior occupation as a proxy within this case law, one can stant to see why.

See supra note 11.

Cf. Ponley, supra note 113 at para. 50 (referring to a Métis right as "a right that we recognize as par of the special aboriginal relationship to the land").

Cf. my previous comments on this: Dwight G. Newman, Commming and Collective Rights (D.Phil. Thesis, Oxford University, 2005) [unpublished] an 236-38 [Newman, Commmity].

Cf. MeNcil. "Aboriginal Title," supra note 17 at 307 (stating that Delgammukn. "acknowledges the unique qualities of Aboriginal title and provides jurisdictional space for self-gotemment").

An inspiring judicial recognition of such explanations appears in The Manogna (Stumo) dwas Tingmi Community' ". Nicaragme (2001), Inter-Am. (1. H.R. (Ser. C) No. 79) at para. 149) (stating that "If for indigenous communities, relations to the land are not merely a matter of possession and production, but [have] a material and spiritual element which ihey must fully enjoy. even to preserve their cultural legacy and transmit it to future generations"). For examples of Aboriginal theorists who express Aboriginal relationships to land claims in spiritual terms see, e.g., Henderson, supra note 93 at $119-45$. Cf. Tumer, supra note 78 at 109-10, 115-16. 
Some statements in the case law actually refer to prior occupation in terms that suggest that its importance arises not from a physical fact of occupation but from an interaction of legal systems. So, Lamer C.J.C. writes in Delgamuukw that "from a theoretical standpoint, aboriginal title arises out of prior occupation of the land by aboriginal peoples and out of the relationship between the common law and pre-existing systems of aboriginal law."130 In so doing, he develops, to an extent, the insights contained in the dissenting judgment of McLachlin J. in Van der Peet. There, McLachlin J. had been at pains to stress the relevance of Aboriginal laws against what she saw as an overemphasis on a particular historical moment in Lamer C.J.C.'s judgment in the case insofar as he required proof that a practice be traceable to pre-contact times to found an Aboriginal right. She wrote: "Aboriginal rights find their source not in a magic moment of European contact, but in the traditional laws and customs of the aboriginal people in question." 131

These kinds of references to the relevance of Aboriginal laws alongside other matters like prior occupation, by no means isolated references, ${ }^{132}$ arguably open an intellectual space to further a reinterpretation of the cases founded on a normative account of prior occupation. Never fully normatively developed in the case law, prior occupation is discussed alongside other concepts that offer alternative modes of understanding the emerging doctrine.

Indeed, there is no difficulty in finding even more explicit suggestions that the Court has actually seen prior occupation as a proxy for something else. Later in his decision in Delgamuukw, Lamer C.J.C. refers to prior occupation as indicative of the relationship of a community to its land, writing that

the law of aboriginal tille does not only seck to determine the historic rights of aboriginal peoples to land: it also secks to afford legal protection to prior occupation in the present-day. Implicit in the prolection of historic palterns of occupation is a recognition of the importance of the continuity of the relationship of an aboriginal community to its land over time. ${ }^{133}$

One reading of this passage is that the historical occupation is normatively important today because of the normative force of a continuing community relationship with land. Chief Justice Lamer's explanation of how Delgammukw applies and appropriately modifies the Van der Peet test makes the connection of prior occupation to community relationships even clearer. He writes that "under the test for aboriginal title, the requirement that the land be integral to the distinctive culture of the claimants is subsumed by the requirement of occupancy." ${ }^{34}$ Prior occupation becomes the measure of cultural connections.

Reading prior occupation as a proxy for Aboriginal community connections to the land thus emerges as a natural way to read Delgamunkw, in which, of course, the Court seemed ready to admit substantial use of Aboriginal oral history identifying community relationships

Delgammukw, stupra nole 1 at para. 145.

Vain cler Pe'el, supra note 1 at para. 247.

See also ibid, at para. 30 (referring to prior-cxisting Aboriginal communities): Delgamumkw, supra note 1 at para. 126 (prior occupation related to "pre-existing systems of aboriginal law"); and Marshall/ Bernard, supra note 1 at para. 129 (referring to "prior social organization" of Aboriginal groups).

Delgamukw, ibid.

Ibid. at pari. 142. 
with land. ${ }^{135}$ Does the Marshall/Bernard concern with relatively strict proof of exclusive occupation $^{136}$ betray the Delgamumkw' legacy and call for an irreversible change to the applicable normative analysis? We can try to grapple with this question through careful attention to the claims actually at stake in Marshall/Bernard.

In applying the translation approach developed in Marshall/Bernard, McLachlin C.J.C. suggests that in a decision on Aboriginal title, "we are required to consider whether the practices of aboriginal peoples at the time of sovereignty compare with the core notions of common law title to land. It would be wrong to look for indicia of aboriginal title in deeds or Euro-centric assertions of ownership. Rather, we must look for the equivalent in the aboriginal culture at issue. $" 137$ The concept of prior occupation, then, becomes a standard against which the Aboriginal practices and culture are to be measured for whether they reveal a community connection with the land that can be recognized and continued only through Aboriginal title or whether the connection they reveal is better recognized through Aboriginal rights other than Aboriginal title. Aboriginal practices and culture are to be considered carefully against this standard.

Chief Justice McLachlin does, in fact, refer in Marshall/Bernard to the application of legal standards to the use of Aboriginal oral history. ${ }^{138}$ This emphasis continues a trend in the case law since Delgamumkw to try to make clear that its authorization of using Aboriginal oral history did not transform all evidentiary rules. ${ }^{139}$ This is, admittedly, one way in which the law has approached matters more rigourously post-Delgamukww.

However, the nature of prior occupation as a proxy for community connections to the land continues as a subtext within the comments on the prior occupation element of the $A$ boriginal title test. It is in the evidentiary considerations that we likely find the reason for the Court's continuing insistence on prior occupation per se. As I have argued at greater length elsewhere, what will or will not be provable, or what will or will not give a rule that may be applied in the circumstances of real life, can itself offer normative reasons for a rule that might differ from the rule most accurately sketching the normative considerations in the absence of evidentiary issues. ${ }^{\mid+1}$ Prior occupation is more objectively measurable, in the Court's view, than community connections to the land per se. Nonetheless, realizing where the normative force of prior occupation resides can enable some rethinking of the applicable rules in the modern doctrine of Aboriginal title.

ith See text accompanying supro notes $36-43$.

13. Marshall/Bernard, supro note 1 at para. 61.

13* Ibid. at para. 70.

130 See generally 1)wight G. New man, "Tsilhyor in Nation w: Brifish Cohtumbia and Civil Justice: Analyging the Procedural Interaction of Evidentiary Principles and Aboriginal Oral Ilistory" (2005) 43 Alta. L. Rev. 433 at $442-44$.

ist See ibid. at $438-40$. 


\section{Conclusion: \\ IMPLICATIONS FOR TIIE DOCTRINE OF ABORIGINAL. TITLE}

If prior occupation is indeed a convenient proxy rather than being inherently normatively determinative, this conclusion has important implications for the form of the Aboriginal title test the Court properly applies. Prior occupation may serve in the general case as a useful proxy for community connections to land, but prior occupation itself should be regarded as neither necessary nor sufficient to make out a case for Aboriginal tille.

First, prior occupation will not be necessary in circumstances where a particular Aboriginal group can provide compelling evidence of a sufficiently deep community connection to particular lands that may or may not have been objects of that group's prior occupation. The community connection to the land must be sufficiently deep such that the land is centrally connected to the cultural-political identity of the group - and centrally connected in ways making recognition of Aboriginal title, as opposed to some other Aboriginal right, the most appropriate way of recognizing the particular connection at issue. If this is the case, then there is reason for the courts to respect that connection regardless of the absence of prior occupation. This situation may clearly arise, for instance, in respect of certain sacred sites irrespective of whether they were sites of prior occupation or whether the occupation of those sites has been discontinuous or evolved only in more recent times. ${ }^{1+2}$

Second, prior occupation will not be sufficient to give rise to Aboriginal title in circumstances in which another group can provide compelling evidence of its overriding connection to or dependence on particular lands. ${ }^{143}$ If Métis groups can establish their overriding community connection to particular lands, they may have a legally recognizable claim to Métis title as against a competing Aboriginal title claim. ${ }^{144}$ The implications do not, however, end there. There will be other kinds of instances in which this more normatively coherent account may have implications that limit Aboriginal title claims. Some will even strike some readers as bizarre. Consider the real controversies that have arisen between Aboriginal claims to certain sacred sites and claims made by latter-day New Age spiritualists also identifying those sites as sacred. ${ }^{145}$ Provided that the New Age believers can establish genuine religious beliefs, it would, quite frankly, be immoral to laugh them off as some might be inclined to do. It will be necessary in some such instances to lind genuine reconciliations between Aboriginal title claims and other claims. Indeed, although settlers' claims that they use various resources in economically efficient manners do not provide them normatively legitimate arguments for dispossession of Aboriginal groups, under-recognized cultural and political connections of non-Aboriginal Canadians to lands (and their possible economic dependence on them) may also establish limits on Aboriginal title. ${ }^{\text {1.46 }}$

14: For a lascinating recent account of sacred sites in Canadian jurisprudence, sec Michael Lec Ross. First Nations Sacred Sites in Cancila s Courts (Vancouver: UBC Press. 2005).

14. Cf. Newman, Community, supra note 127.

it1 Cf. George, supra note 118 at 1224-25 (on genuine claims by two groups to the same object).

is Sec Brown, sipra note 91 at 162-63.

ith $\quad C f$. Jorge M. Valadez, Defiberative Denocracy. Iolitical legitimacy, and Self-Determination in Multiculiural Societies (Buulder. Colo.: Westview, 2001) at 286-88. Note that these cannot all be left for the justification stage, partly because the justification tests are not sufficiently well-articulated $(c f$. generally Peter W. Ilogg, "Interpreting the Charter of Rights: Generosity and Justification" (1990) 28 Osgoode Hall L.J. 817) and partly because cven recognizing title in the first place, and then saying there 
Admitting that this normative account will limit some Aboriginal title claims is an act of intellectual forthrightness. It would be easier to hide within ambiguities and the obvious fact that this normative account is fleshed out here only to the extent that it can be within the confines of a single article. To the extent that some writers' approaches implicitly judge tests for any new doctrinal or theoretical pronouncement by the immediate litigation interests of Aboriginal groups. ${ }^{177}$ they are engaged in a different enterprise. It is not one concerned with normative coherence of the law so much as with refashioning bargaining positions. There are understandable reasons for such an enterprise in light of the historical injustices $\wedge$ boriginal people have faced, ${ }^{1+x}$ but the courts must engage in a task recognizing legitimate interests on all sides of the disputes before them. ${ }^{149}$

Aboriginal title claims have, no doubt, functioned as a way of seeking an economic base for different Aboriginal communities. in some cases successfully. But not everything that is right is a matter of rights. It is right for the government to work with Aboriginal communities to find ways for them to participate in the modern economy, but not every policy in support of that aim will flow from the law of $A$ boriginal rights. Thinking otherwise puts us all in the hands of a dangerous lawyers' game.

Seeking a normative account behind the Aboriginal title jurisprudence of the Supreme Court exposes, at once, a schism in the Court's own principles. In this article, I have sought to further a more normatively coherent account of Aboriginal title by putting on the examination table the prior occupation element of the Aboriginal title test. 1 have reached conclusions with which some may not agree: if so. I hope we may engage in further academic discussion to further understandings. I would not advance the claims I have if I knew they were wrong; however, if one were never to advance a claim without absolute certainty as to its correctness. all scholarship in the area of $A$ boriginal rights would likely cease. Thus. I put my claims forward with intellectual humility in the hopes of furthering the kind of normative discussion of Aboriginal rights topics that is of great policy importance and great significance to justice in Canada.

On the argument I have offered here, making normative sense of the prior occupation element of the Court's Aboriginal title test actually pushes one toward a significant

is a justified limitation, has divisive possibilities (cf gencrally Karin I.ehmann, "Aboriginal Tille, Indigenous Rights and the Right lo (ulture" (2004) 20 S.A.J.II.K. 86).

Cf. supro nole 17, although other authors would more dramatically illustrale the poinl. Cf, also Cairns, supra note 72 at 175-82 (clescribing the potentially narrow locus of academic legal scholarship on Aboriginal issues).

But of. generally Charles I: Abernathy. "Advocacy Scholarship and Aflirmative Action," Book Revicw of The New Color Line: Hol Quofes and Privilege Desfroy Democracy by Paul Craig Roberts \&

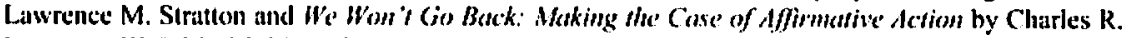
Lawrence III \& Mari J. Matsuda. (1997) 86 (ico. L.J. 377.

The courts should grapple with these interests beciulse they are part of s. 35. although it is entircly understandable that they see the lask before them as so complex as to be approaclied only through broader-based ncgotiations: Dwight G. Newnan, "Negolialed Rights linlirement" (2006) 69 Sask. L.. Rev. 119. I have written there on the prospect that shifling Aboriginal rights issues to negotiations Iranslorms them from malters of what is normatively right into who has bargaining power (ihid.). Such effects problematize those processes and creale incentives for individuals to undertake academic enterprises concerned with refashioning bargaining posilions. But the proper places of adjudication and negotiation on Aboriginal rights issues is a complex matter and better left for fuller treatment clsewhere. 
reinterpretation of that same element. On my account, prior occupation serves and ought to serve as a proxy for community connections to land, which should be the primary matter at stake. Aboriginal title, as conceived within the Supreme Court of Canada's Aboriginal rights jurisprudence, then, is properly a particular form of Aboriginal right more than a particular property claim. Recognizing the prior occupation element for what it is enables greater consistency with this central point about the nature of Aboriginal title and opens space for a more normatively coherent account of the law. The prospect then arises of moving beyond a schism between historically-oriented and forward-looking principles to secking a principled way of dealing with the real interests at stake; of finding principled reconciliations between Aboriginal cultural, political, and spiritual rootedness in Turtle Island and the simultaneously legitimate identity-based and justice-based claims of all Canadians. 